\title{
Contrary to expectation-a case of left-sided acute appendicitis
}

\author{
Sophie Bertaud, Sara Badvie
}

Department of General Surgery, Barnet General Hospital, London, Hertfordshire, UK

Correspondence to Dr Sophie Bertaud, sophie_bertaud@hotmail.co.uk

\section{DESCRIPTION}

A 30-year-old physiotherapist with known Kartagener's syndrome presented with left iliac fossa pain of 2-day duration, associated with nausea and fever. Confirmation of mirror image anatomy and acute left-sided appendicitis was made on CT scan and subsequently at laparoscopy, which were performed with all equipment, staff and ports positioned in a mirror image of the standard approach. The operating surgeon (SB) is ambidextrous, which simplified technical aspects. Laparoscopic views demonstrated abdominal organs placed on the opposite side to our usual expectations; figure 1 shows the liver in the left upper quadrant with the splenic flexure lying on the right, and figure 2 demonstrates the caecum in the left iliac fossa with an inflamed appendix in the centre of the image.

Kartagener's syndrome describes a triad of situs inversus, sinusitis and bronchiectasis, and is thought to be related to cilia dysfunction. Reports of acute appendicitis in

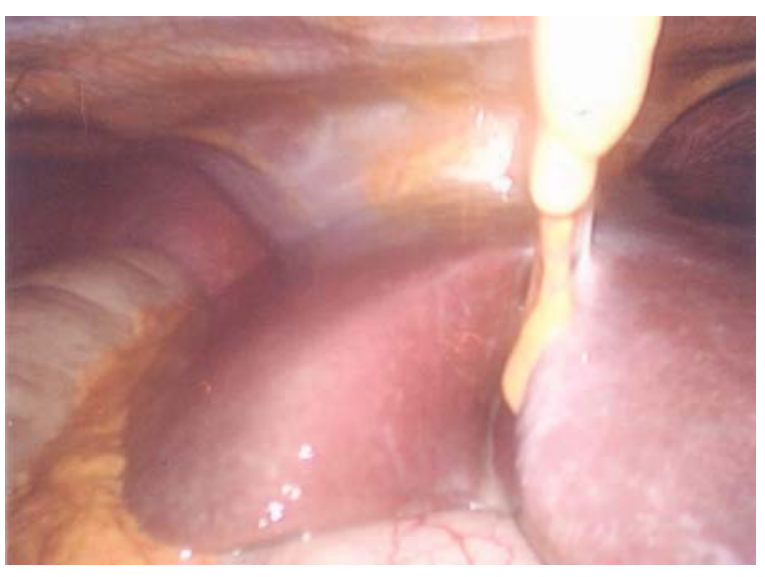

Figure 1 Liver in the left upper quadrant with the splenic flexure lying on the right.

Kartagener's syndrome are extremely limited ${ }^{1}$ and anaesthetic considerations are relevant in this multiorgan disorder. The majority of patients will be aware of their underlying condition at presentation, and a careful medical history is essential in establishing an appropriate differential diagnosis for abdominal pain in these patients. A small

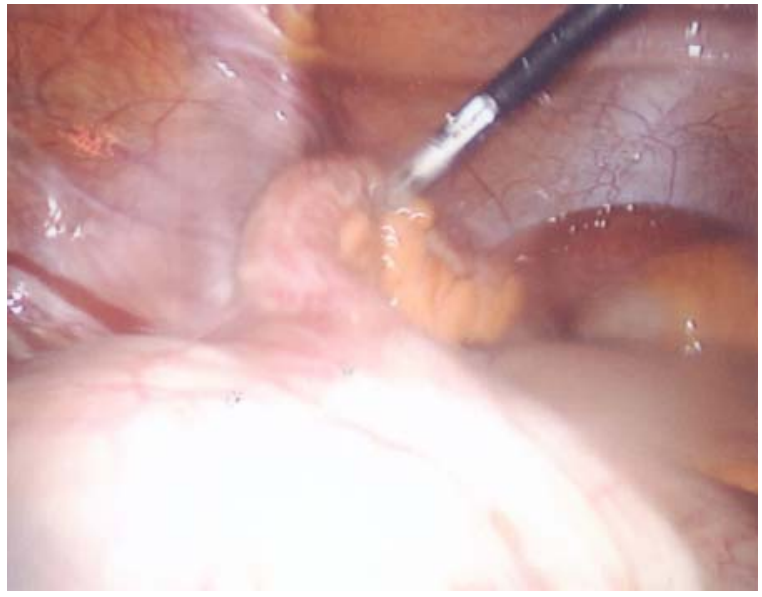

Figure 2 The caecum in the left iliac fossa with an inflamed appendix in the centre of the image.

minority are diagnosed only intraoperatively, although this is becoming increasingly rare in the context of current preoperative imaging modalities.Although left-sided appendicitis is a rare cause of acute left iliac fossa pain, an awareness of such a possibility is needed, given the significant clinical consequences of missed appendicitis.

\section{Learning points}

- Kartagener's syndrome describes a triad of situs inversus, sinusitis and bronchiectasis.

- Acute appendicitis is common, and may occur in patients who have rare syndromes.

- Acute appendicitis in Kartagener's syndrome is a rare presentation necessitating a careful medical history.

Competing interests None.

Patient consent Obtained.

\section{REFERENCE}

1. Kashif A, Masud M, Manzoor SM, et al. Kartagener's syndrome and acute appendicitis. J Ayub Med Coll Abbottabad 2010;22:176-7. 


\section{BMJ Case Reports}

This pdf has been created automatically from the final edited text and images.

Copyright 2012 BMJ Publishing Group. All rights reserved. For permission to reuse any of this content visit http://group.bmj.com/group/rights-licensing/permissions.

BMJ Case Report Fellows may re-use this article for personal use and teaching without any further permission.

Please cite this article as follows (you will need to access the article online to obtain the date of publication).

Bertaud S, Badvie S. Contrary to expectation—a case of left-sided acute appendicitis. BMJ Case Reports 2012;10.1136/bcr-2012-006552, Published XXX

Become a Fellow of BMJ Case Reports today and you can:

- Submit as many cases as you like

- Enjoy fast sympathetic peer review and rapid publication of accepted articles

- Access all the published articles

- Re-use any of the published material for personal use and teaching without further permission

For information on Institutional Fellowships contact consortiasales@bmjgroup.com

Visit casereports.bmj.com for more articles like this and to become a Fellow 